\title{
Becoming Indivisible in the Age of Cloning: Resistance, Individuality, and Photography in Notre vie dans les forêts
}

\section{Sonja Stojanovic}

Number 115, Winter 2020

Précisions sur les sciences dans l'oeuvre de Marie Darrieussecq

URI: https://id.erudit.org/iderudit/1067885ar

DOI: https://doi.org/10.7202/1067885ar

See table of contents

Publisher(s)

Department of French, Dalhousie University

ISSN

0711-8813 (print)

2562-8704 (digital)

Explore this journal

Cite this article

Stojanovic, S. (2020). Becoming Indivisible in the Age of Cloning: Resistance, Individuality, and Photography in Notre vie dans les forêts. Dalhousie French Studies, (115), 75-88. https://doi.org/10.7202/1067885ar

\section{Article abstract}

After broaching the topic in two short stories included in the collection Zoo (2006) - "Quand je me sens très fatiguée le soir" and "Mon mari le clone" Marie Darrieussecq, in her most recent novel Notre vie dans les forêts (2017), returns to the question of clones. In an age when high-tech surveillance and meticulous tracking mechanisms have become the norm, in a world where clones are used as spare parts to prolong one's life, a group of rebels decides to resist and liberate their cloned halves, only to find out that they are also clones themselves; from their hiding place in a forest, the dying female narrator writes her story in a notebook hoping she will be remembered. This article considers how clones can be said to have a distinct and unique identity by tracing the evolution of the female narrator from clone to individual. It also proposes to read the novel as a powerful series of snapshots that allow the narrator, through her photographic writing, to become her own ghost, as opposed to someone else's clone.
This document is protected by copyright law. Use of the services of Érudit (including reproduction) is subject to its terms and conditions, which can be viewed online.

https://apropos.erudit.org/en/users/policy-on-use/ 


\title{
Becoming Indivisible in the Age of Cloning: Resistance, Individuality, and Photography in Notre vie dans les forêts
}

\author{
Sonja Stojanovic
}

"Le monde s'assombrit. Ou peut-être ce n'est pas le monde qui s'assombrit, c'est moi qui suis soustraite au monde tel qu'il était, plus aéré et lumineux."

(Ryoko Sekiguchi, La Voix sombre)

? $\mathrm{n}$ the summer of 1997, Marie Darrieussecq is barely emerging from the media circus and international frenzy surrounding the publication of her first novel Truismes (1996) ${ }^{1}$. Speaking of the press clippings kept in file cabinets by her publisher P.O.L, Darrieussecq shares that "[s]on premier roman, occupe à lui seul plusieurs cartons" (Goldszal n. pag.). As Anneliese Depoux explains in her analysis of the novel's reception and its "événementialisation", the publication of Truismes was truly a global event (73). As mentions of a growing number of foreign-rights sales appeared in the press, it only intensified the novel's success in France (76). That year, on the set of various television programs, Darrieussecq has to field a slew of indiscreet questions unrelated to the novel itself, and to justify both her desire to write and her supposed mental state ${ }^{2}$.

The author also has to remind her audience - eager perhaps to draw certain conclusions - that what they see and read in the media does not correspond to who she is: "Ce que je vois dans les médias, ce n'est pas moi, c'est un personnage de fiction que sont en train de créer les médias, et auquel je participe évidemment" ("Marie Darrieussecq Truismes" n. pag.). As if to prove her point, Darrieussecq's next original work of fiction ${ }^{3}$, the short story "Quand je me sens très fatiguée le soir" (contributed to the revue L'Infini helmed by Philippe Sollers at Gallimard), features a clone in "sleep-mode" named Marie, who is visited once a month by an unnamed female narrator who expresses the desire to unplug Marie in order to truly be able to dialogue with her ${ }^{4}$. She also, and more importantly perhaps, wishes to be able to rest alongside her, after a bad day at work, and fantasizes about "[s]e glisser dans le lit et la prendre dans [s]es bras et dormir avec elle. Mais ça vraiment, on ne peut pas" (Zoo 18). As was suggested to Colette Trout: "Ne peut-on y voir une mise en scène assez humoristique de l'écrivaine en train d'écrire sur son propre double ?" (34) We can also consider the fact that the prohibition of side-by-side sleep points to its potential as a form of resistance to a capitalist mode of production: for, "[s]leep will always collide with the demands of a 24/7 universe" (Crary 10). If, as we will see, clones are merely spares, conceived as collateral and made for the sole purpose of enabling the worker to toil, labor, and consume more and longer, what use is this if both the clone and the worker are asleep?

1 Darrieussecq's second novel Naissance des fantômes will be published a few months later in February 1998, thus escaping the intense scrutiny of the Fall's rentrée littéraire and the annual literary awards season.

2 Her writing about a woman turning into a sow, about a cochonne, manifestly upset or titillated some sensibilities. For a telling compilation of Darrieussecq's various television appearances, see the television report entitled "L'ironie du sort," which aired on the channel France 3 in 1996 as part of the literary television program Qu'estce qu'elle dit Zazie; it is embedded on P.O.L's site dedicated to the novel ("Marie Darrieussecq Truismes" n. pag.).

3 That same summer, Darrieussecq also published a reworked short story, Nathanaël, "une nouvelle tirée des premières pages d'un roman ... que j'avais commencé en 1987. Elle a été publiée par Les Inrockuptibles dans leur recueil Dix, chez Grasset, en 1997" (Zoo 249-50).

4 The text is republished in the short story collection Zoo (2006). I am using this edition throughout the article. 
In this article, I will focus more closely on this text's second life, twenty years later, in the form of a novel titled Notre vie dans les forêts (2017) that is still very much concerned with questions of resistance, of doubling, and of reproduction broadly understood $^{5}$. In the novel, Darrieussecq returns to the subject of clones through the musings of a female narrator living in a dystopian society who joins up with a group of rebels and finds herself in the midst of a crisis: she first believes that she has a clone (she also names her Marie), whose organs she can use as needed in a health crisis, before finding out that she too is but a clone herself, a clone whose organs have been harvested throughout the years for someone else. In the novel, it turns out that each clone is one half of a twisted twin study: "un endormi, qui ne s'use pas, [...] l'autre dans la jungle du monde. [...] Un qui cherche du travail et un logement, pendant que l'autre ronfle dans du tissu de survie. On croirait une émission de téléréalité" (178). Looking at cloning as a mechanism that (erroneously) appears to reproduce more of the same, I propose that, in this tale of collective resistance, the narrator must nevertheless embrace and develop (even if at times somewhat reluctantly) her individuality: from signs of independence such as accepting to sleep alone and giving herself a new name, to recognizing her own personhood. I am also interested in how photography, a different type of mechanical reproduction, is used by the narrator as a tool that can ensure her survival; photographic writing will ultimately allow this narrator - a clone - to be remembered after her death and through a spectral survival as her own person (or as her own ghost) as opposed to someone else's clone or approximate copy.

\section{Reproductions}

Ever since Truismes, scientific knowledge and progress have been an important part of Darrieussecq's oeuvre, and not only on a thematic level: she has integrated the description of various scientific processes in her writing as a means to show rather than tell ${ }^{6}$, and has explored, in novels like Bref séjour chez les vivants (2001) and Le Pays (2005), the narrative possibilities afforded by "cette conscience de participer à un cosmos" (Jordan and Darrieussecq 142). As Anne Simon has proposed, Darrieussecq can be said to be drawn to science due to its capacity to bring up new avenues for thought: "L'imaginaire scientifique contemporain voire technologique parle à Marie Darrieussecq peut-être parce qu'il ne nous a jamais autant demandé de mettre en branle, précisément, notre imaginaire" (23). Through the narrator's own questions about her and Marie's identity as clones, Notre vie also interrogates and pushes back the limits of the human, and invites us to consider what makes us who we are, and how we are to be remembered.

Both in the short story and the novel, these clone projects begin with the ' 69 generation and it can make us wonder whether this is a deliberate decision meant as a political statement: "On peut se demander si la date 1968 est significative puisqu'elle se réfère, dans l'imaginaire collectif des Français et Françaises, aux grandes mutations sociales de la société. Ironiquement, ces changements auraient amené le clonage et toutes sortes de problèmes que les scientifiques n'avaient pas prévus" (Trout 137). While it is also possible that Marie Darrieussecq could simply be making a reference to her own year of birth, 1969, there is not only something ironic, but definitely something cynical at play, in the choice of this date. Though Trout rightly suggests that "Darrieussecq parait mettre en

5 In an interview with Shirley Jordan published in 2012, Darrieussecq mentions wanting to revisit her short story and rework it into a novel: "ça fait très longtemps que j'ai envie d'aller franchement du côté de la science-fiction - parce que je la frôle souvent ... j'ai aussi très envie de retravailler sur la question du clone" (133).

6 She credits author Nathalie Sarraute with giving her "la force de ne pas écrire "Elle se sentait très angoissée"" (Darrieussecq and Lambeth 809). The detailed depiction of the changes happening in the body of a protagonist is a deliberate narrative choice and one of the ways through which Darrieussecq makes the reader understand what is happening to her character: at the end of White (2003), the meticulous description (on a cellular level) of the process of conception is the only announcement of Edmée Blanco's pregnancy. 
garde contre une science sans conscience", and that science-fiction, the very genre that the author chooses for her fiction, "permet justement cette liberté de critiquer notre monde contemporain en projetant dans le futur des développements qui sont en train de naître dans notre société" (138), there is, nevertheless, something to be said about the bleakness that emanates from the two stories, which hints at the fact that perhaps certain revolutions are, in the end, futile when we are too far gone; maybe we are, indeed, already too late when it comes to fixing ourselves. But whether or not change can happen from knowing the world as/for what it is, Darrieussecq's fiction encourages us to question the underpinnings of certain received ideas, and forces us to think about our own position as readers (and citizens).

The topic of cloning is particularly interesting given that it "combines both art and industry, artifice and technology" (Harris 28); we could also say that it fosters a dialogue between the humanities and the sciences that touches upon ontological, epistemological, and biopolitical questions. John Harris, in describing how "[t]he fascination of cloning" reveals a larger and more pervasive obsession that posits the human as a god, argues that it reveals an "urge and desire to reproduce 'things' and ourselves. To clone ourselves is to be at once a consummate artist and a divine creator" (28). However, in both the short story and the novel, the impetus for cloning stems from another type of divine envy: it reveals a desire for immortality, not necessarily "a way of making a photo or Xerox copy of ourselves that would replace us and survive to clone/copy itself again indefinitely down the ages," but to ensure that we use these copies to prolong our own life for as long as possible (Harris 26). Darrieussecq's texts thus emphasize the frailty and finite nature of the human body, which needs to be remedied, and it is something that even clones, like our narrator, experience; indeed, we are told at the beginning of the novel that she is about to die. We find out that her body has been weakened because her souche (the woman whose clone she is) has been using her to prolong her own life: cloning is thus understood as a survival mechanism, "une assurance-vie" (52). Though, it is a survival at the expense of clones and it testifies to a focus on the future rather than a replication of the past or an urge to create something; as we will see later, the so-called "Pygmalion syndrome" is something that clones - not humans proper - experience (86). Furthermore, the narrator's admission, "J'ai de la nostalgie pour le futur" (42), testifies to the fact that her own future is stunted, it is a future that she will not see as she is about to die; it is the future survival of the souche that has always been priviledged. And it is the realization of her own cloneness that prompts the narrator to change her views: while she had always been bothered by the idea that she was the recipient of Marie's organs (it turns out she was not), she never refused the transplants, which were presented to her as a necessity. This changes when the narrator learns that she is also a clone and she is then fully (though perhaps self-servingly) opposed to "cet usage de nous" (184). By refusing to take an organ from Marie, the narrator must accept her impending death, and she thus needs to find a different way to survive.

It is with this frame of mind that I want to read Darrieusseq's novel as a powerful series of photographic snapshots. Indeed, the single eye that opens at the beginning of Notre vie can certainly be read as the opening of a photographic camera shutter: "J'ai ouvert l'œil et boum, tout m'est apparu. C'était limpide" (9). The inclusion of the onomatopoeia "boum" further underscores the instantaneity of the realization - we can say the flash -, and even the references to clarity and light ("apparu", "limpide") hitting the eye and revealing important details mirror the process of photographic exposure. Reading this novel in such a way allows for a certain transfer to take place. If cloning is a type of mechanical reproduction that can be harnessed in order to extend one's lifespan, photography, or, more precisely, photographic writing, can also be understood to propose a life-extension benefit. 


\section{The Uniqueness of Clones}

"[T] o what extent is the clone a replica (its DNA determining its identity) or a tabula rasa, upon which upbringing and the environment inscribe identity and individuality?" (Rye 118) With this question Gill Rye aptly summarizes the debate concerning the identity of clones. While one could be tempted to argue along with Jean Baudrillard in Simulacres et simulation that cloning ultimately contributes to the loss of a unique subject, that such a technological advancement "rend possible la génération d'êtres identiques, sans qu'il puisse être jamais fait retour à un être originel" (152; emphasis in original), it would mean forgetting one crucial piece of this process. And that is exactly what Maria Aline Ferreira calls out: "Here, as in many other passages from his work, I have problems with Baudrillard's sensationalist pronouncements, his facile equation of clones with serial human beings and his erasure of the person whose set of genes gave origin to a given cloned person" (26). It is indeed important to emphasize that, cloning, as it is represented in Darrieussecq's novel, stresses the great difference between the first subject who provides his or her genes and the subsequently cloned versions.

In Notre vie, the revelation of the identity of this person is particularly significant as it exposes the cruelty of the entire operation, which is predicated on a system of economic inequality. As the narrator watches a stolen video, she notices a group of people whose lives are entirely different from hers: they live in relative idleness and solely engage in pleasurable consumption. She then notices that these people - who are white, old, and rich - are the only ones who actually benefit from the engineering of clones because it affords them - and them only - the possibility of living longer:

Tous blancs, je veux dire bronzés par le soleil mais blancs. Au vu de l'âge général de ces vieillards riches, qu'on nomme [...] les souches, il n'y a pas une, mais plusieurs Générations [...] Ils usent un clone puis deux puis trois puis quatre, etc. Ils les dépiautent en série. De plus, beaucoup de ces souches ont eu des bioenfants, qui eux-mêmes ont eu droit à leurs doubles ou à leurs triples, pas à de simples jarres d'organes comme les gens disons simplement aisés. Seuls les super-riches de la planète peuvent se payer des clones. (176; emphasis in original)

The cruelty of this realization is compounded by the fact that there is one old woman featured in the video who looks at the camera with an eye that the narrator recognizes as once belonging to her: "Elle ne m'avait pas seulement pris mon œil mais aussi mes paupières [...]. Avec mes rangées de cils, avec mon canal lacrymal" (175). It is a consumption that knows no bounds because it is not only the eye, or, more precisely, the cornea, which is taken, but actually the entire eye, and the eyelids, and the tearducts - this is something that is currently only undertaken "as part of a full-face transplant" (Turbert $\mathrm{n}$. pag.). The suggestion is, then, that the souche has begun to take over the narrator's own face, her identity, and will ultimately scavenge (dépiauter) all her organs/pieces in order to survive for a while longer. This is confirmed when the narrator fully recognizes herself in this woman - "C'était moi" (174) -, though she also immediately understands both the consequences and impossibility of such a statement: "Moi quand je n'aurai jamais cet âge. Parce que moi je vais mourir bientôt avec ce qui me reste de morceaux de mon corps" (174). The starkest difference between the souche and the moitie (the moniker given to clones) is that one is born for the consumption of the other. There is no identification possible between these two types of beings: not only are their lives radically different from a socio-economic and biopolitical standpoint, but their purpose is entirely predicated on which side of the cloning process they are on.

Walter Benjamin's oft cited The Work of Art in the Age of Mechanical Reproduction is certainly "an indispensable reference" when writing about clones, especially, as we have seen, when they embody "commodity production" of the highest order: the manufacturing 
of human spare parts for nearly-unlimited consumption by those with the proper means (Ferreira 25). While Baudrillard reads Benjamin to argue for the loss of the original in the cloning process much like in the advent of photography (151), Ferreira proposes that Benjamin's focus on "the presence of the original" in his discussion of authenticity is actually most helpful when arguing for the "uniqueness of clones" (26). For her, when he claims that "[e]ven the most perfect reproduction of a work of art is lacking in one thing: its presence in time and space, its unique existence at the place where it happens to be" (Benjamin 220), this statement has to be interpreted differently for clones. She writes:

[A] similar argument can be made for the uniqueness of clones, who will always be separate, as far as the time and circumstances in which they are brought up, from those of their genetic mothers or fathers. Given that environment is unreproducible, genetic makeup alone will not be enough to produce identical human beings, since social and cultural surroundings obviously play a fundamental role in a child's development. (27)

In Darrieussecq's 1999 short story "Mon mari le clone" (also included in the collection $\mathrm{Zoo}$ ), the narrator is faced with the very challenge of trying to reproduce a specific environment: in 2022, twenty-one years after the death of her husband, she has him cloned and then attempts to raise him to become the man she once married. While the story can be read as "le scénario ludique de se retrouver avec un partenaire de 50 ans son cadet," it is rather "les difficultés à reproduire l'enfance de son mari alors que le monde a tant changé" that are most productive for thinking about the uniqueness of clones (Trout 138). Even though the narrator was promised that her husband would be the same, "on a la certitude d'obtenir exactement le même individu" (Zoo 226), and even though she conscientiously tries to "suivre le schéma de sa première enfance" (Zoo 227), things are easier said than done - how is one supposed to replicate some fifty years later someone's childhood? -, especially given the fact that the narrator knows her husband's tastes and preferences as an adult ${ }^{7}$. We also only learn of the husband's name - Jean-Jacques (clin d'œil à Rousseau) - as she is attempting to see if her nurture and education of her husband's clone will yield the man she expects. Her awareness and experience that a certain environment must be reproduced in order to yield the same person underscore the fact that it is a determining factor in the construction of one's identity - the husband's clone is only eight years old, and it will take a while before the narrator finds out if her plan will work: "Il y a évidemment des expériences vécues par mon mari que je ne pourrai pas reproduire dans leur exactitude. Je suis obligée de prendre certaines initiatives. Personne n'est encore capable d'anticiper les effets à long terme. Nous verrons bien" (Zoo 228). As Gill Rye explains in a reading of this short story, "Here, then, repetition means difference: the clone cannot be the same person as its original, since generational, environmental, educational and cultural differences intervene" (117). Despite sharing the same genetic material, clones have to be understood as unique given their exposure to a specific environment and given their personal experiences, which shape their identity; they cannot be simply categorized as "serial human beings", a simple "copy/paste" of their original. The long-term effects are also important to consider for the knowledge of their cloneness could also mark an important change in their identity. Who is to say what will happen to this narrator's husband once he realizes that the woman who raised him is the wife of the man whose genetic material he shares.

7 She even refuses to give him to his own mother and sister in order to respect the views she knows he holds as an adult: since his twenties (when they met), he has been voting for the Left, so their "atmosphère de vieilles bourgeoises [...] ne lui convient certes pas" (228). The narrator does not at all account for the fact that this bourgeois upbringing may well be the reason behind his desire for change, and does not realize that, by denying him this aspect of his childhood, she is irremediably changing him. 
When the narrator of Notre vie finally understands who she is, she compares it to the Copernican revolution: she goes from being at the center of her own preoccupations to the realization that she is being "usiné[e] puis démonté[e]" for someone else (182). This absolute shift in her worldview, which we learn in the last ten pages of the novel, happens, chronologically speaking, right after her arrival in the forest. Thus, this discovery stands as the impetus for her narration, "J'écris pour comprendre et témoigner" (15), for she realizes that many others never understood their purpose on this planet (16). While she does not reveal what she knows at the onset of her narrative, her entire project is colored by this uncovering. She finds a new purpose, "je me dis que notre but ultime, notre noblesse finalement, c'est de protéger nos moitiés", a task that she takes very seriously, from refusing to take any organs from Marie, even though she is on the verge of dying, to testifying and leaving a warning for her intended readers (16). But in her recognition that both the moitiés deserve protection and that this task bestows upon her (and her fellow rebels) a certain nobility of spirit, she also differentiates her experience as a clone from Marie's own. If we have established the difference between the souches and the moitiés, there is also a fundamental difference between each of these halves: the narrator and Marie are far from identical.

Even if one could be inclined, in Notre vie, particularly in the case of the "deux moitiés isolées", to see them as an identical replacement of their (deceased) counterpart, upon closer inspection they are anything but perfect replicas. We have José, the moitié of a plane crash victim who, "ça ne s'invente pas - fabriquait de petits avions en bois léger", and Mathias Matéo, the narrator's childhood classmate who had disappeared and whose moitié is described as follows: "et c'était lui, soudain : inchangé, puéril, à demi idiot" (163). However, Mathias Matéo disappeared when he and the narrator were twelve years old (65), so this statement refers to a certain understanding of the moitiés as generally being childlike (and thus her classmate appears as if frozen in time), rather than to the moitie being identical to the person Mathias Matéo would be had he lived (he would, indeed, by then, be an adult like the narrator $)^{8}$. And in the case of José's moitié, the fact that he builds small toy planes does not make him identical to José, who, while he died in a plane crash, is not known to have liked to play with planes; it rather testifies to the fact that "[p]eut-être dans leur sommeil ont-ils quand même vécu quelque chose" (163). While the souches and the moitiés all share the same genetic material, when it comes to the question of identity, their experiences and upbringing, as well as their level of self-consciousness, differentiate them from one another.

In the novel, the understanding of the identity of clones is further developped as we follow the group of rebels, who, after finally freeing a portion of the moitiés, try to raise them, to educate them, and to teach them how to be(have). Even though both groups are clones, they cannot be mistaken for each other: "on ne peut évidemment pas les prendre pour nous, qui avons accumulé tant d'expériences, subi tant d'épreuves, vaincu tant d'obstacles. Mais on ne sait jamais. On ne sait jamais ce qui pourrait leur passer par la tête" (125; my emphasis). The narrator even remarks that although she sleeps next to her moitié Marie, "dès son réveil, elle courait vers les autres moitiés" (164). Marie identifies with the other moitiés rather than with the one who shares her genetic material; the moitiés are happiest among themselves, they form a community of which the narrator is not a part. At the end of the novel, we find out that the narrator is all alone, all but abandoned by Marie: "Je suis couchée au fond d'une galerie. [...] Marie, je ne la vois plus. Je ne sais pas ce qu'elle devient. La chochotte ne me rend jamais visite. La chienne" (168-69). The narrator's futile desire and Platonic vision of an ever-loving harmonious (re)united pair referenced in the slogan "U-nis-sons / nos moi-tiés !" (104; emphasis in original) - cannot

8 In "Quand je me sens très fatiguée le soir", Mathias Mathéo [sic] does not disappear mysteriously but actually strangles his clone and thus ruins one part of a scientific study of a rare disease (Zoo 16). 
prevail. She must learn to fend for herself. The problem is, so to speak, that the moitiés have just woken up without a past, and as such, are not interested in anything but the immediate gratification of their (animal) instincts: "Aucun sens politique, aucun désir métaphysique, aucun élan vers l'avenir. Tout au présent. Certes, elles n'ont pas de passé. C'est difficile à penser" (126). Having been asleep, both literally and politically, the moitiés live in the now, and are, in a sense, deeply individualistic: they cannot see themselves as part of a community and are certainly not preoccupied about the consequences of their actions for the newly-founded rebel society. While our narrator must accept to rely on herself and be at peace without Marie, all the moitiés will have to learn to consider others' needs. In this context, one of the most dangerous consequences of this distinctness of experience is summed up in the very possibility that the freed moitiés, not understanding the political stakes of their very existence, will turn in the rebels who liberated them from the centers (125).

The moitiés experienced an awakening to the world that can be compared to a birth via Caesarean section: "Autrefois, les bébés qui naissaient par césarienne, on les appelait 'les bébés étonnés'. Parce qu'ils n'avaient pas lutté pour sortir du corps de leur mère. Parce qu'ils n'avaient pas subi les contractions. Ils étaient nés sans transition" (169) ${ }^{9}$. While our narrator brings up this image to talk about her own self, about the fact that sometimes she is also "tout étonnée" (169) by her new discoveries, this idea of a sudden change of states not backed by gradual experiences can explain why our narrator sees her own stunned moitié as someone yet to be created, someone who does not share her own identity nor the identity of their souche, but someone who can, with the appropriate moulding, become as unique as Pygmalion's statue: "Je ne sais pas pourquoi, moi je la voyais comme l'avenir. Une page blanche à écrire. Toute cette disponibilité. Ce matériau brut, en quelque sorte. Beaucoup parmi nous ont eu le syndrome de Pygmalion" (86). However, in the context of her work as a trauma counselor, the narrator also explains that the sudden move from one state to the next, "l'absence de transition", is what makes recovery painful and long (27). While the rebels are clones who benefitted from experiential learning, the moitiés woke up in an adult body without transition, and are thus uninterested and uninvested in the fight and resistance against the system that manufactured them - whether they even comprehend the implications of their cloneness is to be debated. One can assume that given enough time, the moitiés will grow out of this stupefied stage (and since it is said to constitute the basis for philosophy ${ }^{10}$, there is certainly hope for them) and they will perhaps develop on an intellectual or metaphysical plane. After all, even speaking on solely etymological terms, there is room for growth: “[o]n ne pense pas assez à ce que c'est, un arbre. D'ailleurs le mot clone a pour racine le grec $\kappa \lambda \omega ́ v$ qui veut dire "jeune pousse" (103). However, despite this potentially promising future for the moitie, our narrator is running out of time: she is dying, and she will neither see nor be able to report on what the future may hold. Instead on focusing on moulding her moitié, she has to start thinking about her own self and her legacy. She needs to decide what is important to her: being reunited with Marie, her moitié, or becoming her own person and leaving a trace behind. For the only way for the narrator to become whole is by fully accepting and cultivating her individuality, despite the disappointment and solitude that certainly come with it.

9 This description also appears in Darrieussecq's autofiction Le Pays (233-34).

10 Socrates, in Plato's Theaetetus, speaking to the young man stunned by his method says "for this is an experience which is characteristic of a philosopher, this wondering: this is where philosophy begins and nowhere else" (19). This is reiterated by Aristotle, "it is because of wondering at things that humans, both now and at first, began to do philosophy" (5). In Le Pays, the narrator identifies the stunned baby as asking himself/herself the question "où suis-je" over and over. For her, this is the first spark of thought, and, consequently, of humanity (234). 


\section{Becoming a Person Again}

Already in "Quand je me sens très fatiguée le soir," we find out that the narrator refuses to use the number assigned to her clone, and instead bestows a name upon her (the code and subsequent name will remain the same in Notre vie): "2690175102008 (je l'appelle Marie)" (Zoo 14). Significant for our purposes, the identification actually corresponds to a French social security number ${ }^{11}$, which gives us valuable information as to the clone's and possibly the narrator's biographical data: 2690175102 008. I translate: a woman, born in 1969, in January, in Paris, $2^{\mathrm{e}}$ arrondissement, the eighth born in the same place during the same timeframe ${ }^{12}$. Because Darrieussecq, in addition to her first name and profession (psychoanalyst), shares some biographical data with these characters - year and month of birth (January 1969), though not place of birth (Bayonne) -, it would be easy to simply see this as a playful mise en fiction on the author's part, a creation of yet another layer of doubling or cloning within the narrative.

Yet, this blurring of lines also contributes to making this woman's emancipation all the more meaningful (out of one social security number we get four characters - at least!). Growing up, the narrator of Notre vie conceived of herself as a human being and someone who has a clone, although the relationship was complicated even if the two had not physically met yet: “j'étais parasitée. Par ma moitié. Par Marie. Je ne pouvais pas faire comme si Marie n'existait pas" (51). As our narrator slowly discovers the circumstances of her birth, "ce que je devinais devenait intolérable" (49), she has to reconfigure her vision of herself. When she later disappears into the woods, she chooses a completely different name: instead of her given name Marie (and the repetition or reproduction of her author's name), which she assigns to her moitié, she chooses "Viviane" as her "nom de fugitive" (13). The name Viviane, which comes from the Latin vivus (alive), showcases a possible answer to the narrator's existential questioning: whence she came does not negate that she is undeniably alive (at least for the time being). When, getting sicker and sicker, Viviane deplores the fact that there is no grammatically-correct way to refer to a certain communal understanding of the relationship between clones, she unwittingly learns something else from the moitie that she always thought she was, she becomes a single moi - and the word moitie is literally halved:

J'aimerais écrire 'nous m'avons entourée de lainages', parce que ce sont les nôtres qui s'occupent de moi. Mais bizarrement, on ne peut pas écrire ça. Dans aucune langue, je crois. Je suis obligée d'écrire 'ils me', pas 'nous me'. Je découvre. Ça fait assez longtemps que j'écris maintenant, mais je trouve encore des trucs. Si je n'écrivais pas je me demanderais ce que je fais là, dans ce trou, dans ce groupe". (169; emphasis in original)

Through the experience of writing, of thinking of herself in and through language, Viviane grasps both what it means to be part of a different sort of community but also what it means to be an individual, that is, etymologically speaking, indivisible (Lat. Individuus). She is someone to whom something is done by others: whether negatively, when her organs are harvested for the taking by her souche, or, positively speaking, when she is someone who is cared for by a group of other beings. And thus, even though she is an integral part of a

11 For an explanation of the various categories, see "Attribution du numéro de sécurité sociale".

12 This is the number given in "Quand je me sens très fatiguée". In Notre vie, this number is used again but two more digits -80 - are added (63); perhaps reflecting the control key number that is used to verify the accuracy of the number, although the math does not add up. According to a website that calculates control key numbers, the correct key for such a social security number would be 75 (Madore n. pag.). Another option is that it reflects an entirely different timeframe - perhaps 2069 or 2169 -, the narrator does repeatedly make mention of events that happened in the 20th and 21 st centuries in such a way that would suggest that she is further removed from our own time. 
group of rebels, the singularity of her voice is what becomes critical to the retelling of her story.

For Viviane has been aware that this is her last chance to tell it, and that it is imperative that this story be told. The injunction at the start of the novel - "Du nerf. Il faut que je raconte cette histoire. Il faut que j'essaie de comprendre en mettant les choses bout à bout. En rameutant les morceaux. Parce que ça ne va pas. C'est pas bon, là, tout ça. Pas bon du tout" (9) - recalls the urgency that characterizes the beginning of Truismes : "Mais il faut que j'écrive ce livre sans plus tarder, parce que si on me retrouve dans l'état où je suis maintenant, personne ne voudra ni m'écouter ni me croire" (9). The reference is not insignificant, for Truismes is a novel that, through its narrator's exploration of her becoming-animal, also poses the question of what it means to live and be remembered as a human being with her own trajectory (she ends up living mostly on her own, and mostly in pig-form, yet she nevertheless chooses to reach out by writing her story). For her part, Viviane finally manages to relinquish her past desires of a genuine sisterly reunion with Marie, whom she calls a fussy wuss, "la Chochotte" at the beginning of the novel (which, as I mentioned, chronologically speaking, comes after she finds out that she is also a clone herself) (9); her priorities have shifted. Her main focus is, in the end, to leave a legacy behind in the form of the notebook that makes up the novel:

Je voudrais être sûre, si un jour quelqu'un trouve ce cahier dans la forêt, enterré dans le bidon, peut-être avec mes ossements, je voudrais être sûre qu'avant de le détruire, ou, je ne sais pas, de dire que j'ai tout inventé, ou de le tourner en dérision, bref, je voudrais être sûre qu'il soit lu jusqu'au bout. C'est tout. ${ }^{1}$

${ }^{1}$ Et ne croyez pas que je ne sois pas sûre de ne pas être une non-personne. (186)

Knowing that "pour perturber un robot, il faut abuser des doubles négations" (53), Viviane, in a convoluted sentence of multiple negatives, sends a message that will be gibberish to the all-too-literal robots, and asks us, it seems, to believe (in) her. Viviane's testament is about being remembered as a person who lived and passed, and thus as a singular yet significant member of a larger human readerly community. Could we then perhaps understand her plea, despite what a careful grammatical parsing of the sentence may yield - if the robots are too literal, then perhaps we should not be -, as an ultimate wish, a coded sentence signifying resistance? Croyez que je suis sûre d'être une personne !

\section{Photographic Writing}

Even though Viviane is the product of mechanical reproduction, even though she was engineered for someone else's benefit, she still expresses the desire to be remembered as a person with her own story. In this final section, considering a different type of (mechanical) reproduction, I will focus on Viviane's photographic writing and its potential for ensuring a spectral survival; this is the last step in her evolution from clone to full-fledged individual. As has been noted above, because she is fast approaching death, she is very concerned with the urgency to get her message across while she is still able to write - and the way that she writes is particularly significant for understanding her journey to individuality. For, if the novel feels unedited, it is because it was written fast:

Laissez-moi d'abord vous décrire ma situation actuelle, maintenant tout de suite : parce que je sens qu'il faut que j'aille vite. J'ai peu de temps. Je le sens à mes os, à mes muscles. À l'œil qui me reste. Je suis mal en point. Je n'aurai pas le temps de relire. Ni de faire un plan. Ça va venir comme ça vient. Alors :

je vois autour de moi un campement dans une forêt. Des tentes et des bâches. Des trous. Des braseros dans des bidons. Le couvert des arbres qui nous protège des drones. Une connexion pirate et quelques robots bricolés. Des toilettes sèches et une gestion de fer. Un retour aux fondamentaux. (10-1; my emphasis) 
Viviane warns us at the beginning of her tale that it will come as it goes: "Ne comptez pas sur moi pour organiser tout ça. J'essaie de suivre un fil chronologique mais ça rate" (26). Throughout the narrative, this lack of organization is emphasized by the repeated inclusion of interjections, which relentlessly jolt us out of our reading, out of the story Viviane is trying to tell.

We get to see the seams, where the fragments that make up the text are woven together, and it can surely be said that these interjections create a certain constancy through a unity of voice: since this is the story of someone who has a hard time keeping track of everything, then all the utterances that break up the narration are the mark of authenticity. Viviane uses three variations of the same question, which interrupt the tale on at least fourteen occasions: "Où j'en étais", "Où en étais-je?", and "J'en étais où". We are also given several repetitions of "Reprenons", about fifteen "Bon", coupled with a few occurrences of "Sale époque", and about thirty or so interruptions of "Bref", "Bah", and "Ha!". We also see her trying to give herself strength with several iterations of "Du nerf"; and sometimes these interjections are even paired together: "Reprenons. Du nerf. J'ai froid" (16). Finally, towards the end of the novel, we feel the pace increasing with the exhortation, "Vite", which appears five times in the last thirty pages of the novel. Moreover, we also come across the constant reminder, intensifying in the final pages, that Viviane is about to die: "J'ai froid". However, this also creates a certain distance: we are constantly reminded that we are reading a book in the process of being written. Rather than keeping us enthralled in the dystopian world that she has created, Darrieussecq, through the voice of her narrator Viviane, emphasizes that Notre vie is just as much a story about clones trying to escape an oppressive society as the portrait of a writer at work.

The narrator proceeds with her story through what can be likened to a photographic approach. Akane Kawakami, in her book Photobiography, proposes three ways of understanding this term: "literal[ly], metaphorical[ly], and analogical[ly]" (6). At the beginning of this article, I suggested that the eye that opens the novel could be read as a photographic camera shutter, and, for Kawakami, this is precisely when the text can be called "photographic" in a metaphorical sense, since "photography enters a text as a metaphor, that is to say already in the form of language" (6; emphasis in original). Throughout the text, we can see that Viviane continues to use her eye as a lens and that she does not take the time to frame her shots (cadrer un plan), which means that things are mentioned to us as she thinks of them (as we can see in the block quotation above). Viviane's comment likewise reminds us that what we are given to read is akin to an instant snapshot, with no retouches, no elaborate background and props: a simple Polaroid, taken in the moment. As Kawakami suggests, the "use of the term 'cliché' [snapshot], as opposed to 'photographie', denotes the manner of their taking (snapshots are photos taken on the hoof, swiftly), and therefore connotes a lack of constructedness or structural planning. There is also, therefore, a sense that snapshots are more likely to represent reality in its most authentic state (as opposed to a staged photograph)" (51). Just as the interjections are one way of affirming her story's authenticity, the fragmented retellings of her life in the woods make it seem as if we readers are flipping through her photo album, turning the pages somewhat out of order, and getting a clearer picture of who this person is because we are slowly able to "mett[re] les choses bout à bout. En rameutant les morceaux" (9). But rather than representing an authentic reality where we could easily compare the photograph to the scene photographed, the way that Viviane's literary snapshots work is that they give us a sense of who is taking the shots, of who she is. Here, the construction of the photographer is more important than what is photographed.

While Notre vie is not exactly a photobiography, where authors also include actual photographs along with their texts (the literal sense of a "photographic text" to which Kawakami refers), photographs are mentioned several times in the novel - and in a rather negative sense. The character who ultimately helps the narrator realize that she (and all 
those belonging to the same group of rebels) is also a clone works as a cliqueur and his work consists, in part, of associating words with images for the benefit of robot education (17); it is an extremely depressing and distressing profession, which lands him in therapy (with Viviane). For him, photographs are marks of traumas that need to be drowned out. The other photographs in the novel are not described and they do not provide valuable information, comfort, or solace, but rather emphasize the narrator's isolation ${ }^{13}$. When speaking about her childhood, Viviane points out that despite not having met Marie (yet), photos were, for reasons that are obvious, unnecessary: "je ne l'avais encore jamais rencontrée physiquement, ni vue en photo, à quoi bon" (52). When Viviane is later diagnosed with prosopagnosia, a cognitive disorder, she becomes unable to recognize faces, even in pictures of her mother: "[e]t le comble : sur les photos, ma mère, je ne la reconnaissais pas, en 3 ou même en 4D" (94). This foreshadows the realization that her mother is not her (biological) mother, and it is her eye, which is destined to later serve its purpose as a spare part for her souche, that already betrays a certain foreknowledge of her nature as a clone. Viviane will gradually become dispossessed of parts of her body, and, the real comble, is actually that the woman whose genes were used to engineer her - her "genetic mother" of sorts - is the one who is stripping her for spares. "Literal" photographs are thus not useful for the narrator because the reality that she finds herself in (before her decision to flee to the forest) is constructed on lies (her mother is not her biological mother, her clone is not her clone, she is also a clone). Even if the photographs are in 3 and 4D more holograms than photographs - there is a disconnect between what she knows and what she does or does not see, and thus the pictures cannot be trusted as a way to grasp and understand or even accurately represent her world. They complicate the notion that there is a certain referent that can be recorded and attested or accessed through photography. If the identity of the referent is perpetually unstable, always shifting as new knowledge becomes available, who is to say which aspects (if any) will be exposed on the photograph? Photography, in this context, serves a different purpose.

Before fleeing to the forest and understanding her position within the system, our narrator believing she was slated to receive an eye transplant, went for a surgical procedure, not realizing at the time that she was actually the donor, and that it was her eye that was destined to be given to her souche (she unsuspectingly had already provided a lung and a kidney). One will recall that this later contributes to the cruelty of the revelation of her status as a clone: Viviane truly understands who she is as she looks at her own eye, now located in the face of another. One of the effects of this particular surgery - the removal of one of her eyes - is that she now sees the world as if it were a (2D) photograph: "C'est très pénible, de ne voir que d'un œil. Ça change la vision des choses, et pas en bien. Ça diminue le monde et surtout, ça l'applatit." (36; my emphasis). If, "literal" photographs were shown to be an unreliable way of rendering the world, when Viviane's lone eye is the lens from which her photographic writing stems, it provides a more accurate portrayal of the situation: the reason why Viviane's world has been diminished is quite possibility because she thought she was a souche, an original, when she was a clone all along (a clone who is now missing parts of her body). In the process of becoming flat, the world also becomes readable, that is, graspable. Despite the initial disappointment, her new way of viewing the world finally represents it and her own self more accurately: she knows who she is, she knows why she sees the world in this way, and she has her own unique story to tell. And just as the novel literally started with an eye-opening scene, it will end when the narrator closes her eye for the last time: "Je ne vois plus très bien. Je ne filtre plus très bien quoi

13 In contrast, the narrator of "Mon mari le clone" keeps pictures of the moment her deceased husband's cells are taken in order to create a clone of him, though it is unclear what exactly she is immortalizing: "La société préleva solennellement un nombre calculé de cellules, et je signai les formulaires, en qualité de témoin. J'ai gardé de nombreuses photos de ce moment" (Zoo 225). 
que ce soit. Je ne vois plus les arbres, parce que probablement, je suis gardée à l'intérieur des galeries. J'ai froid. J'ai l'impression que je suis seule maintenant" (189). When she no longer sees, when she no longer curates what we can see, the novel ends. It is thus within a tightly confined frame that we are given to follow the evolution of the narrator's selfconsciousness and her journey from clone to individual.

Reading the novel as a series of snapshots taken through Viviane's lens is particularly productive when we consider the fact that photography has the potential to extend one's life, albeit in a rather peculiar fashion - and this is where we have to (temporarily) lay aside our rationality and attachment to logical conclusions, this is where we should make a leap into the magical unknown alongside Roland Barthes. Indeed, when it comes to photographic writing, Barthes's La Chambre claire is a landmark text, but it is Elissa Marder's reading of Barthes in The Mother in the Age of Mechanical Reproduction that interests me here, particularly given her attention to the following assertion by Barthes regarding the power of photography:

La photo est littéralement une émanation du référent. D'un corps réel, qui était là, sont parties des radiations qui viennent me toucher, moi qui suis ici ; peu importe la durée de la transmission ; la photo de l'être disparu vient me toucher comme les rayons différés d'une étoile. Une sorte de lien ombilical relie le corps de la chose photographiée à mon regard : la lumière, quoique impalpable, est bien ici un milieu charnel, une peau que je partage avec celui ou celle qui a été photographié. (Barthes 126-27)

For Barthes, photography is literally able to connect two bodies, the one who once was photographed and the one who now looks at the photograph. Marder notes, "Here, we see how photography, whose etymology means 'light writing,' alchemically transforms light into flesh. In this transformation, photography becomes a maternal medium that magically reconnects the body of the viewing subject to the body of the referent by an umbilical cord" (156). The word "magically" is crucial here, for, as Marder suggests a few pages earlier in her book, "Barthes insists that the specific force of photography derives from the physical operation it performs upon the body of the referent" (151). Barthes writes about photography as a way to be reunited with his deceased mother, and he is adamant that there is a possibility for her to actually reach him through photography. He writes, "Quoi qu'elle donne à voir et quelle que soit sa manière, une photo est toujours invisible : ce n'est pas elle qu'on voit. Bref, le référent adhère" (18). As such, the photograph is always more than itself - it gives us something to see that means more than its surface. Yet, according to Marder, Barthes goes even further in his idea of what exactly takes place in the process of taking a photograph. She writes: "[t]he claim that the referent adheres to the photograph motivates almost everything else Barthes has to say about the function of photography. The entire book circles around this claim despite the fact that it remains, at bottom, resolutely unthinkable and hence almost unreadable. Reasonable critics tend to overlook how crazy this idea actually is" (151). Marder goes on to cite Jacques Derrida's attempt "to make philosophical sense of Barthes's outrageous claim" (151) and explains that to do so, "Derrida is forced to read what Barthes meant, rather than what he actually said" (152). For Barthes is concerned with finding his mother again, there is no rational way of going about it, and it is as such that he "insists, contrary to all logic and reason, that he sees, in the photograph, an actual trace of the referent itself. Through his rhetorical excesses and logical inconsistencies, Barthes contends that photography can actually conjure up the (lost) body of the referent" (Marder 152); it is a crazy idea indeed. But rather than dismissing it or interpreting it in a way that makes logical sense (like Derrida), Marder shifts her emphasis from "the perspective of the subject who desires to be reunited with the body of the lost object", that is, Barthes' desire to be reunited with his mother, to "the perspective of the living subject who is subjected by its [photography's] mechanical eye" 
(157). Recalling Barthes's earlier statement that, in being a photographed subject, he experiences a certain death - "je vis alors une micro-expérience de la mort ... je deviens vraiment spectre" (30) -, Marder examines how photography (this "mechanical mother") also has deadly powers:

The living subject who has been photographed risks finding himself face to face with the specter of his own ghost. Because the umbilical cord, which binds the living subject to its photographic image, cannot be cut, photography seizes the body of the living subject, reproduces it, and then returns it as corpse. The living body of the subject haunts the photograph in the form of an undead body that can never be fully buried. The uncanny properties of the photographic medium suspend the body in a perpetual never-never-land between procreation and mortification. (157)

While this coming "face to face with the specter of [one's] own ghost" can leave one perpetually in-between, in the liminal land of the spectral, making one "a living dead," these consequences turn out to be useful when it comes to our clone. If Viviane's eye is indeed a photographic camera that records her singular version of the world, at the end of the novel she quite literally turns the lens on herself and undergoes a tranformation: "Parfois je me figure moi-même dans le bidon. Je me vois, dans le bidon, toute tassée, vivante encore je ne sais trop comment, écrivant encore toute contorsionnée et ne parvenant même plus à lire ce que j'écris" (187). In this out-of-body experience, when through her lens Viviane looks at herself writing, she can be said to come "face to face with the specter of her own ghost"; it is in this moment - as she is about to die - that she no longer is defined as someone else's clone, but she can rather be seen becoming her own ghost.

In the last four pages of the novel, we find Viviane voicing seven times with the repetition of "je voudrais" her desire to be remembered. While she had wanted, at first, to be reunited with Marie, and while she desired to be part of a community - an important part of the group of rebels who resist the conditions of their births - she finally learned (reluctantly at times) to be on her own. At the end of the novel, thinking about her impending death, Viviane asks us to remember her, even for a few seconds, as the woman that she is - not a clone, but a full-fledged person with a distinct voice and a singular story: "[j]e voudrais, s'il vous plaît, si vous trouvez ces ossements dans ce bidon, que vous songiez, quelques secondes, à la femme qui y respirait" (189). By entrusting unto us readers herself and her notebook, Viviane defies the circumstances of her birth. The compilation of snapshots jotted down while on the run in a notebook that recalls the one of Truismes is both Viviane's testimony and her testament, as well as, surely, a transformative tale of resistance. For what is more radical than a clone, a product of the mechanical reproduction of genetic material, who truly becomes an individual through the writing of her story, and who can, in turning her lens to capture her own self, be finally remembered and carried within us readers as a ghost?

University of Notre Dame

\section{WORKS CITED}

Aristotle. Metaphysics. Trans. C.D.C. Reeve. Indianapolis: Hackett Publishing Company, [350 BC] 2016. Print.

Attribution du numéro de sécurité sociale. $<$ http://www.securite-sociale.fr/Le-numerode-securite-sociale $>$. (Accessed 4 February 2018). Web.

Barthes, Roland. La Chambre claire. Note sur la photographie. Paris: Éditions de l'Étoile/ Gallimard/ Le Seuil, 1980. Print.

Baudrillard, Jean. Simulacres et simulation. Paris: Galilée, 1981. Print.

Blade Runner. Dir. Ridley Scott. England: Ladd Company, 1982. 
Benjamin, Walter. "The Work of Art in the Age of Mechanical Reproduction". Illuminations. Trans. Harry Zohn. New York: Schocken Books, 2007. 217-51. Print.

Chaouat, Bruno. Je meurs par morceaux. Chateaubriand. Lille: P U du Septentrion, 1999. Print.

Crary, Jonathan. 24/7. Late Capitalism and the Ends of Sleep. London: Verso, 2014. Print. Darrieussecq, Marie. Truismes. Paris: P.O.L, 1996. Print.

---. Bref séjour chez les vivants. Paris: P.O.L, 2001. Print.

---. White. Paris: P.O.L, 2003. Print.

---. Le Pays. Paris: P.O.L, 2005. Print.

---. Zoo. Paris: P.O.L, 2006. Print.

---. "Marie Darrieussecq Truismes". YouTube. < https://youtu.be/RhqJ65nr0AQ>. (Accessed 6 February 2011). Web.

---. Notre vie dans les forêts. Paris: P.O.L, 2017. Print.

Darrieussecq, Marie and Shirley Jordan. "Entretien avec Marie Darrieussecq". Dalhousie French Studies 98 (2012): 133-46. Print.

Darrieussecq, Marie and John Lambeth. "Entretien avec Marie Darrieussecq". The French Review 79 (2006): 806-18. Print.

Depoux, Anneliese. "La Fabrique de l'événement littéraire : le cas de Truismes". Communication et langages 142 (2004): 71-83. Print.

Ferreira, Maria Aline Salguiero Seabra. I Am the Other: Literary Negotiations of Human Cloning. Westport: Praeger Publishers, 2005. Print.

Goldszal, Clémentine. "La vraie vie des écrivains". Elle. 19 November 2017. $<$ http://www.elle.fr/Loisirs/Livres/News/La-vraie-vie-des-ecrivains-3576872 >. (Accessed 30 January 2018). Web.

Harris, John. On Cloning. London: Routledge, 2004. Print.

Kawakami, Akane. Photobiography: Photographic Self-Writing in Proust, Guibert, Ernaux, Macé. Abingdon: Legenda Modern Humanities Research Association and Routledge, 2013. Print.

Madore, David. Calcul de la clé sécu.

$<$ http://www.madore.org/ david/jscript/secusoc.html >. (Accessed 11 February 2018). Web.

Marder, Elissa. The Mother in the Age of Mechanical Reproduction. New York: Fordham U P, 2012. Print.

Plato. Theaetetus. Trans. M. J. Levett. Ed. Bernard Williams. Indianapolis: Hackett Publishing Company, [369 BC] 1992. Print.

Rye, Gill. "New Representations and Politics of Procreation. Surrogate Motherhood, Artificial Insemination and Human Cloning in Contemporary Women's Writing in France". Women Genre and Circumstance. Essays in Memory of Elizabeth Fallaize. Ed. Margaret Atack, Diana Holmes, Diana Knight and Judith Still. Abingdon: Legenda Modern Humanities Research Association and Routledge, 2012. 109-21. Print.

Sekiguchi, Ryoko. La Voix sombre. Paris: P.O.L, 2015. Print.

Simon, Anne. "Déterritorialisations de Marie Darrieussecq". Dalhousie French Studies 93 (2010): 17-26. Print.

Trout, Colette. Marie Darrieussecq ou voir le monde à neuf. Amsterdam: Brill/Rodopi, 2016. Print.

Turbert, David. "What Parts of the Eye Can Be Transplanted?" American Academy of Ophtalmology. 3 April 2018. < https://www.aao.org/eyehealth/treatments/transplantat ion-eye $>$. (Accessed 16 November 2018). Web. 